\title{
Marketing Profile of Dry Fish in Digha Coast of West Bengal
}

\author{
Soumyadip Purkait ${ }^{1}$, Somen Sahu ${ }^{1 *}$, Bostanul Arefin ${ }^{1}$, Subir Kumar Pradhan ${ }^{1}$, \\ Anisha Sharma ${ }^{1}$, Satyanarayan Boda ${ }^{1}$, Sutanu Karmakar ${ }^{2}$ and Saymantaka Sahu ${ }^{3}$
}

${ }^{1}$ Department of Fishery Economics \& Statistics, Faculty of Fishery Sciences, West Bengal University of Animal and Fishery Sciences, Kolkata-700094, India

${ }^{2}$ Aquatic Environment \& Health Management Division, ICAR-Central Institute of Fisheries Education, Mumbai-400061, India

${ }^{3}$ Departmentof Zoology, City College, University of Calcutta, Kolkata-700009, India

*Corresponding author

\begin{tabular}{|c|c|}
\hline & A B S T R A C T \\
\hline & \multirow{6}{*}{$\begin{array}{l}\text { The present investigation was conducted to throw the light upon the present marketing } \\
\text { status of the dry fish industry in Digha belt of West Bengal. The market was surveyed } \\
\text { from September } 2017 \text { to April } 2018 \text {. The study area was purposively selected, and the } \\
\text { marketing channel, price spread was analyzed. Survey question schedule was made for the } \\
\text { collection of data. Several coastal and marine species used for dry fish production like } \\
\text { Harpodon nehereus, Trichiurus savala, Prawns \& crabs, Sardinella longiceps, } \\
\text { Chirocentrus dorab, Polynemusindicus, Rastraligerkanagurta, Pamapama, Leognathus } \\
\text { sp., Setipinaphasa, Arius sp, Escualos athoracata and Polynemus paradiseus etc. Different } \\
\text { types of marketing intermediaries were involved in the marketing system like the fish } \\
\text { processor, Beparis, Aratdars, Wholesalers, Retailers and exporters The survey depicts that } \\
\text { the maximum dry fish produce from October to January season. The price of dried marine } \\
\text { fish varies with the availability, size and quality of the fish species. The transport system, } \\
\text { labour and electricity also play a significant role in end price determination. The marketing } \\
\text { system is associated with a good employment generation involve men and women in the } \\
\text { coastal belt of the state. The main barrier of the sustainable development of the market is } \\
\text { unhygienic handling, lack of infrastructure, poor road condition etc. }\end{array}$} \\
\hline Keywords & \\
\hline $\begin{array}{l}\text { Dry fish, Marketing } \\
\text { channel, Price spread, } \\
\text { Constrain, Management } \\
\text { strategy }\end{array}$ & \\
\hline Article Info & \\
\hline $\begin{array}{l}\text { Accepted: } \\
\text { 24 September } 2018 \\
\text { Available Online: } \\
\text { 10 October } 2018\end{array}$ & \\
\hline & \\
\hline
\end{tabular}

\section{Introduction}

India ranks seventh in the marine fish production and 2 nd in the inland fish production in the world (Anon, 1993). The total active fisherman inhabitants are 5.5 million, and about 6.8 million people are employed in fishing related activities. West Bengal has a total coastline of $157.5 \mathrm{~km}$ which mainly covers the districts of South and North
24 Parganas and PurbaMedinipur (Dan, 1985). Fish is the integral part of the regular diet for the peoples of West Bengal as a source of protein. About $78 \%$ of the total fish catch is consumed in fresh condition, $6 \%$ is used as dry fish and rest is used as frozen fish. Indian dry fish export contributed $8 \%$ of all form of fish exports and earned INR 7540 million during 2012-2013 (MPEDA, 2013). In India, consumption of dried fishes is about $32 \%$ of 
the total marine landings and about $17 \%$ of the total catch used for the production of dry fishes (Shakila et al., 2003). In drying, salt is used to remove the non-halophilic, sporeforming bacteria and osmophilic fungi (Sivaraman et al., 2015). Dry fish is an essential source of animal protein supplement, which is preferred as a keydish or used as a flavouring agent in combination with other food items. However, all dry fish are in great demand during the fishing ban period when the availability of fresh fish in the market is lower (Das et al., 2013). In case of export dried items have revealed a negative growth of $38.59 \%$ in quantity $28.17 \%$ in rupee value and $32.59 \%$ in USD terms respectively, even though unit value realisation picked up from 2.35 to 2.58 in the year of 2015-16 with a positive growth of $9.77 \%$ (GoWB, 2016). The location where fish landing, as well as drying activity, is undertaken is known as Khuti (Samanta et al., 2016). In Khutis fishes are dried under natural sunlight in bamboo poles in the coastal areas. The majorKhuties located a coastal West Bengal includes Dighamohana, Sankarpur, Jaldha, Junput, Mandarmoni, Petuaghatetc (Payra et al., 2016).

These khuties have produced 10152 tons dry fish during 2015-16 (GoWB, 2016). Thus the study was conducted to throw the light on the present status of the fish drying and to identify the main constraints related to this industry and to formulate some management strategy to facilitate profitable marketing.

\section{Materials and Methods}

\section{Sampling frame}

To assess the present status of fish drying Digha coast firstly Ramnagar-I and Deshapran block from Contai sub-division was purposively selected as representative from the district of Purba Medinipur. Then from two selected block three khuti, viz.
Junputkhuti, Jaldahkhuti and Dighamohonakhuti were chosen by random sampling. A list of 150 dry fish processor connected with fish drying who are living in the surrounding area of the selected Khutis was prepared and thirty Khuti owners and dry fish processors were randomly selected for questionnaire and interview. Similarly, thirty auctioneers, thirty wholesalers and thirty retailers were also randomly selected for marketing analysis through interview and questionnaires.

\section{Questionnaires and data collection}

The questionnaire was developed in a logical sequence of that the target group could answer chronologically. For this study, a combination of the questionnaire, interview, Participatory Rural Appraisal (PRA) tool such as Focus Group Discussion (FGD) and cross-check interviews with key informants were used.

\section{Data collection}

Secondary data were collected from the available sources. Primary data were collected in 2017 using pretested structured questionnaires and interview in the local language and subsequently converted to English. Collected data were suitably categorized, tabulated for interpretations, generalizations and implications.

\section{Data analysis}

All the collected data were reduced to tabular form using standard statistical methods. Microsoft Excel 2010 was used for the representation of data and results. The constrains and suggestions were measured by a scale developed by Haque (1981), the respondents were asked to mention the most important constrain and suggestions as perceived by them and ranked them according to the majority. 


\section{Results and Discussion}

\section{The process of fish drying observed}

Even though salting is a cheap and simple method of processing requiring least technical expertise, it has huge significance and relevance in the socioeconomic system of small-scale fisher folk (Felicia and Patterson, 2003). The dried fishes are having ample market in West Bengal, neighbouring states, and overseas as sun-driedfishes are considered as the predominant food bringing vital protein to people in rural areas of least developed countries (Graikoski, 1973).

The process of fish drying is carried out through different stages. After collection of fish, they used it for processing. In the initial stages, fishes are washed, cleaned and then grading is done according to the species, size and quality. After grading, fishers are kept in a cemented tank for salting.

Usually, $30-35 \mathrm{~kg}$ salt is mix with $100 \mathrm{~kg}$ of fish. Salting process in done about 3-4 hours, then fishes are transferred into different means of drying unit. It was also observed that the smaller fishes were directly dried under the sun without any types of dressing. The findings agreed with the findings with Samad et al., (2009).

Mainly two phases are there in the drying stage. In the first phase the water on the surface of the fish evaporates, and the rate of drying depends on surface area of the fish (size), the speed of air movement over the fish and relative humidity of the air.

The second phase occurs when the surface of the fish has evaporated. The drying rate in this phase depends on:

The nature of the fish. Fat in fish flesh retards water movement,
Fish shape. The thicker the fish, the longer the time of drying,

Temperature. Drying will proceed more rapidly at higher temperatures,

Water content. The higher the water content, the longer the time of drying (Clucas, 1982).

In each khuti, it was observed that drying yard is having concreted floor whereas in the majority of the areas they use straw and plastic (locally called "Tripol") over the ground and spread the fishes. For Bombay duck and ribbon fish they mainly use a bamboo made structure which is locally called "pata". The drying activity is completely carried out on a commercial basis. While observing the ownership pattern, both partnership, as well as sole ownership, was there in the dry fish business. Both drying and salting (curing) are executed in the same area, and from among the various methods of drying, the method of sun drying is only carried out in this area.

The pre-drying stage and post-drying stage involves the employment of men as well as women for the whole process, but the involvement of women is about $70 \%$.

The study exposes the lack of hygiene in the drying process as the major drawback. All 3 selected khutis are following the traditional sun-drying method, and hence the hygienic conditions are not satisfactory. During the time of drying the fishes are getting polluted by the blow-flies, stray dogs, and microorganisms which makes it highly unsafe for human consumption. Similar results were pointed out by Immaculate et al., (2013), Bhat et al., (2013) and Shyam et al., (2016) in their studies at Tuticorin villages and Kashmir valleys, respectively. Mainly the women who are directly involved in the drying process suffer from various skin diseases and gynaecological problems. 
The drying process of fish usually operates from the end of the August to May, as there will be sufficient sunlight and less atmospheric moisture content for the proper drying of the fish during this time period. The availability of raw materials may also affect the drying activity. The daily operations in Khutistart by spreading the fish at 8 am and ends up with the gathering back of fishes by 6 pm. Instead of the popular method of rack drying, open ground drying is followed in the DighaKhuti where as in JunputKhuti and JakdahKhuti rack drying is mostly observed. Small fishes like Escualosa thoracata, Setipinna phasa and shrimp-like Metapenaeus monoceros need an average time period of 1418 hours in the sun to get dried completely, whereas Harpodon nehereus and Trichiurus savala takes an average of 20-24 hours to get dried. Medium sized or fatty fishes like Rastraliger kanagurta takes almost 26-28 hours in the sun to get dried up. Small fishes were directly taken for drying without much dressing up. Similar findings are there in the study conducted by Samad et al., (2009).

The fishes are turned over at regular intervals by the workers to quicken the drying process. The study conducted by Soegiyono (1994) also reports the same procedure of turning the sequentially arranged fishes upside down at regular intervals to accelerate the drying process. Fishes are taken back to the tent by 6 $\mathrm{pm}$, as the salted fish absorbs moisture from surrounding when the relative humidity rises during the night or rainy time. Fishes are accumulated and covered inside the tent to reduce the absorption of moisture. High humidity levels may cause the re-absorption of moisture by the dried fish and become susceptible to bacteria, fungal or insect attack (Azam, 2002).

The duration of drying varies from 2 to 5 days depending on the size of the raw fishes, availability of sunlight, relative humidity, the surface area of fish, etc. In case of cloudy weather, more days are required for complete drying. The lean fishes such as Bombay duck, Ribbon fish etc. loses almost 80-90 per cent of their original weight, after proper drying, whereas fatty fishes like sardine lose 65 per cent, after carrying out a proper sun drying process.

It was observed that low-quality salt was used for the salting process in all Khuties. The production of salted or unsalted dried fish depended on the choice of processor, consumer demand and the market price of the product. But in this study sites, some Khuti owners in Jaldha use salt in fish only in the cloudy weather.

The study conducted by Suparno (1994) in Indonesia reports that the use of impure salts causes the growth of halophilic bacteria and affects the penetration of saltinto the fish flesh. The low-quality salt at a whole sale price of Rs.3-4 per $\mathrm{kg}$ is used in the study area. The used salted water is not changed frequently after washing a batch. The waste water is also dumped in nearby areas. The remaining salts in the waste water are strained, and sun-dried which are used in salting for second-time use in fresh fish. A similar study was observed by Marine et al., 2015.

\section{Sorting of dried fish}

Smaller fishes were remained in mixed condition and were sorted out after dryings. But important species like Bombay duck, ribbon fish, mackerel etc. are sorted before drying. Generally, women workers sorted out the mixed dried fishes and separated the fish according to the species, size and quality of the dried fish. However, sorting of fish could vary from area to area. Flowra et al., (2012) reported that sorting of dried fish was not common in Chalan Beel areas of Bangladesh, but it was only performed after collection of 
raw fishes for drying. This difference might be due to the variation in traditional processing activities of the two study areas.

\section{Packaging and storage}

After drying of fishes, packaging was done by plastic and jute made bags. Sometimes bamboo baskets (locally which are called "Jhuri") are also used for packaging. Generally, one jute bang contains $50 \mathrm{~kg}$ dried fish. Samad et al., (2009) reported that the bagged dried fishes were kept in the tents generally made of thin plastic sheet and bamboo splits for temporary storage until marketing or selling. Gopakumar (1994) reported that packaging materials that were used for dried fish in India were coconut leaf baskets, bamboo baskets, or gunny bags. If any infestation was found during storage of the stored product, sun drying was performed again for 2-3 days and restored as reported by the processors.

\section{Species use for fish drying}

Various types and sizes of fish are used in sun drying. Generally, small fishes are selected for drying than larger ones.

This was because of the availability and market demand of small species. Drying duration of these species varies from 2 to 5 days depending on the size of the raw fishes, availability of sunlight, relative humidity, the surface area of fish and wind action etc.

According to the priority, Harpodon nehereus is the first choice of the respondents for the drying activity, followed by Trichiurus savala, Prawns \& crabs, Sardinella longiceps, Chirocentrus dorab, Polynemus indicus, Rastraligerkanagurta, Pamapama, Leognathus sp., Setipina phasa, Arius sp, Escualosa thoracata and Polynemus paradiseus.

\section{Marketing channel analysis}

During the study, it has been observed that the marketing channel follows the similar pattern to that of other fish products. The dry fish marketing channel starts with a farmer and ends with the ultimate consumer involving a number of intermediaries in between. The involvement of these marketing intermediaries provides services for head loading, packaging and transporting of dry fishes and these activities result in cost addition at every stage of marketing (Bishnoi, 2005).

In three selected khuties Middlemen or Paikersplay a pivotal role in the marketing channel between the Fish curers (who sun drying the raw materials) and wholesaler. The dried fish was found out to be stored in small huts with thatched roofs, near the drying yards. The properly dried fishes are packed in gunny bags and are sold as wholesale to Paikers, who sell the product to Wholesaler, who then sell the product to retailer or export the product with in the country in different states or in the neighbouring country.

In general, the marketing channel is followed as- Fish processor (who catch the fish and process them to end product) $\rightarrow$ Paikers $\rightarrow$ Wholesaler $\rightarrow$ Retailer $\rightarrow$ Consumer, where raw fishes were transferred $100 \%$ to dry fish processer who process the whole drying process and transfer $75 \%$ dry fish to paikers and $25 \%$ to the wholesaler. In the next stage, paikers transfer $90 \%$ of his total fish to the wholesaler and remaining $10 \%$ to the retailer. Wholesaler here divide his total dry fish mainly into three groups, i.e. $35 \%$ to the retailer, $40 \%$ within the country and remaining $25 \%$ he export in a different country. It agrees with the study made by Saha (1970) and Samanta et al., (2016). Figure 1 elaborates the whole marketing channel of dry fishes in the selected study area in PurbaMedinipore district of West Bengal. 
Fig.1 General Marketing Channel and the percentage distribution of dry fishes between different market intermediaries

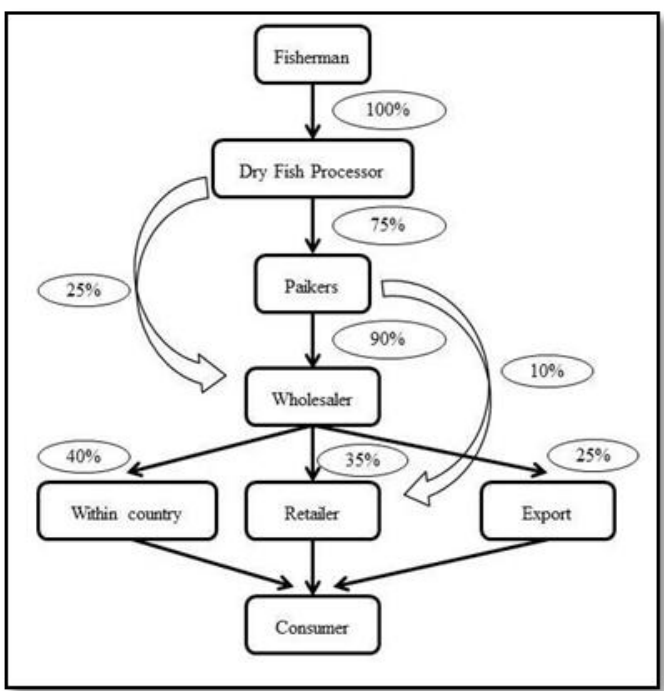

Fig.2 Species wise per kg production price by the processor and respective Consumer/ market price

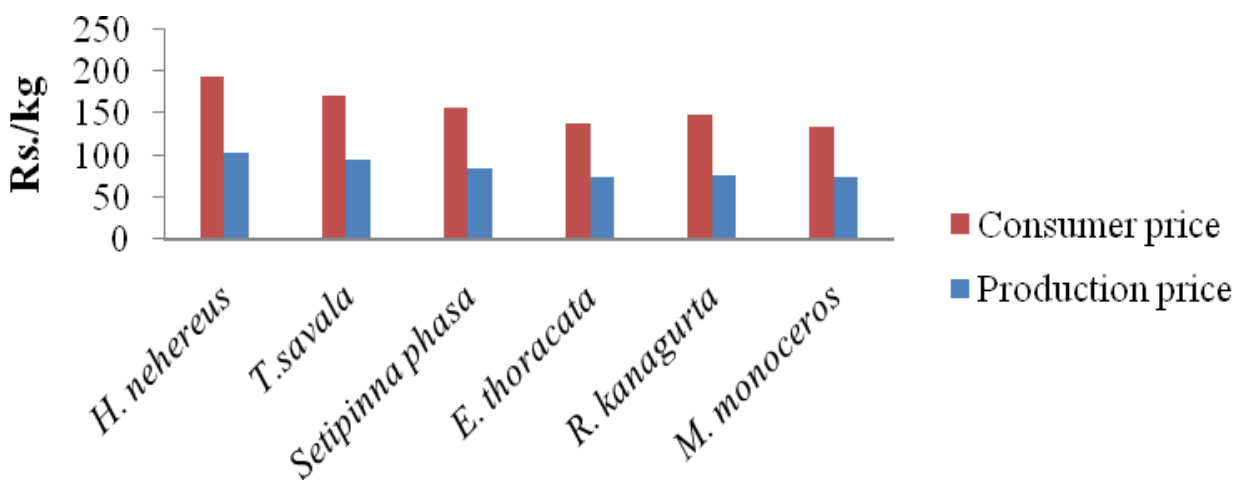

Fig.3 Profit percentage of different marketing intermediaries

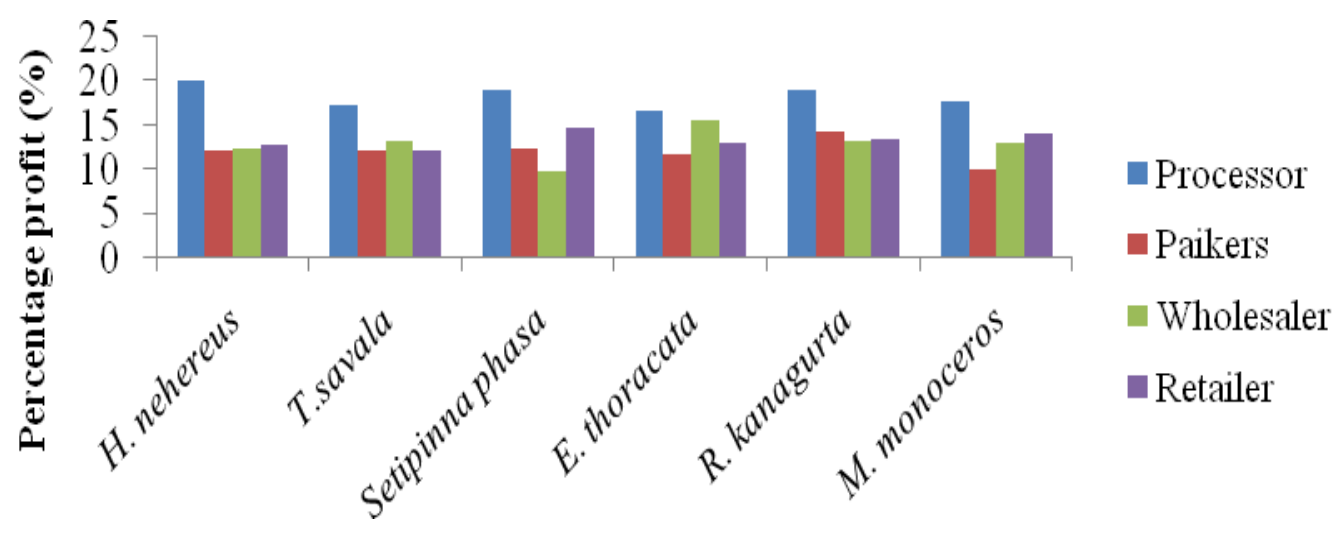


Fig.4 Processing price of different marketing intermediaries

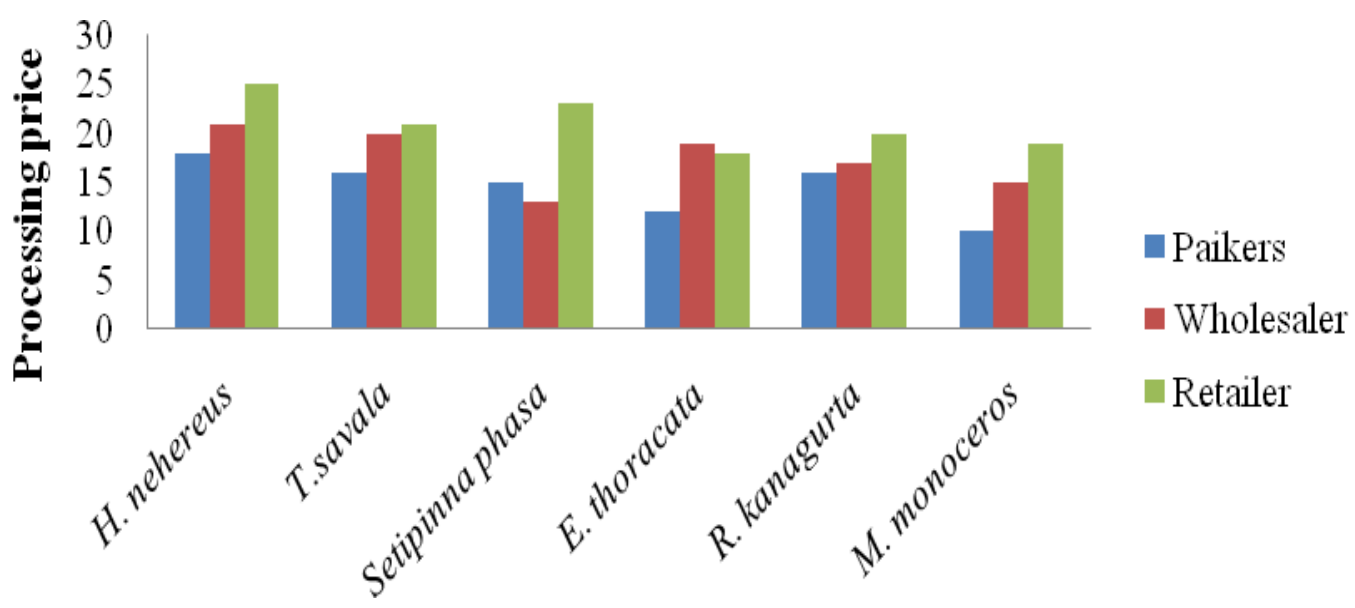

Fig.5 Graphical representation of species-wise selling price through different stages

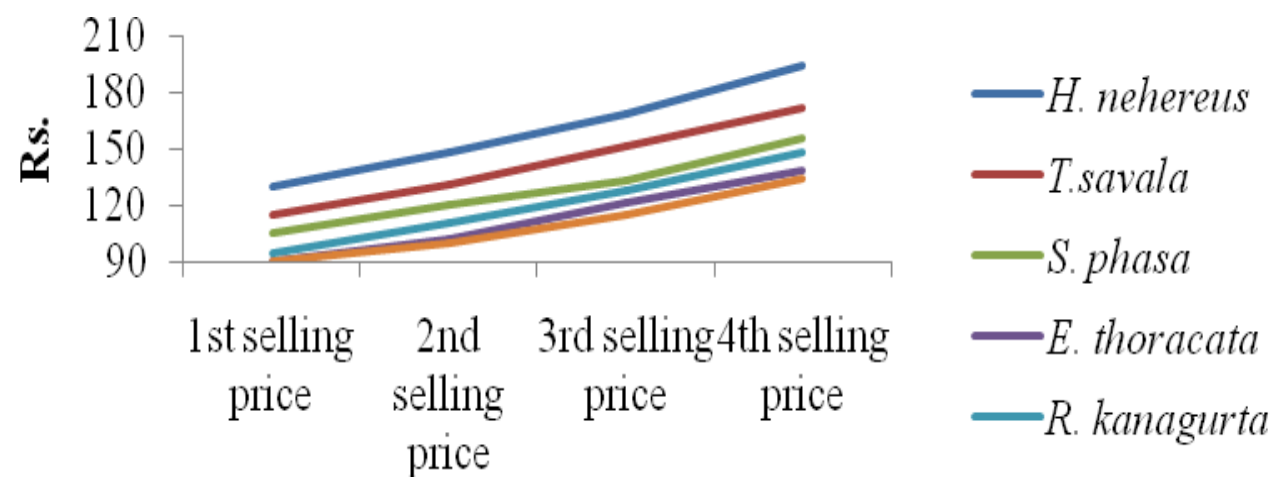

Fig.6 Labour wages and working hours in study areas

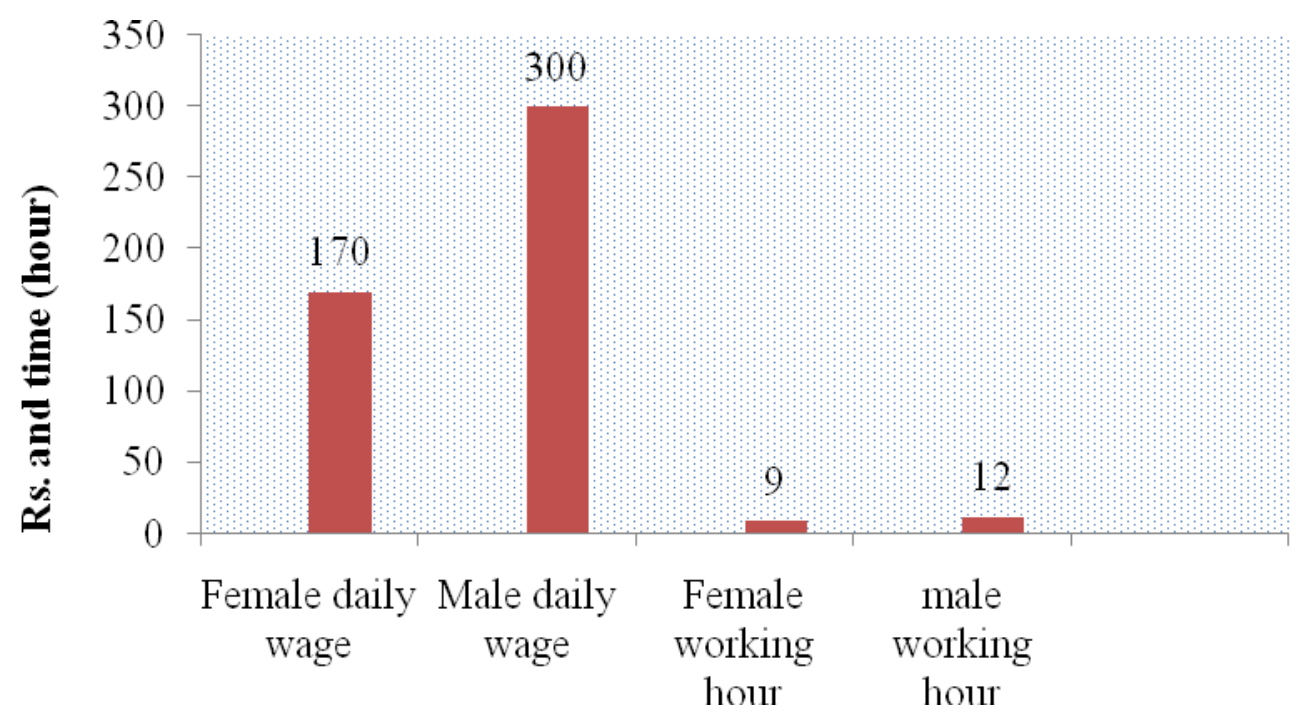


Fig.7 Cause of spoilage

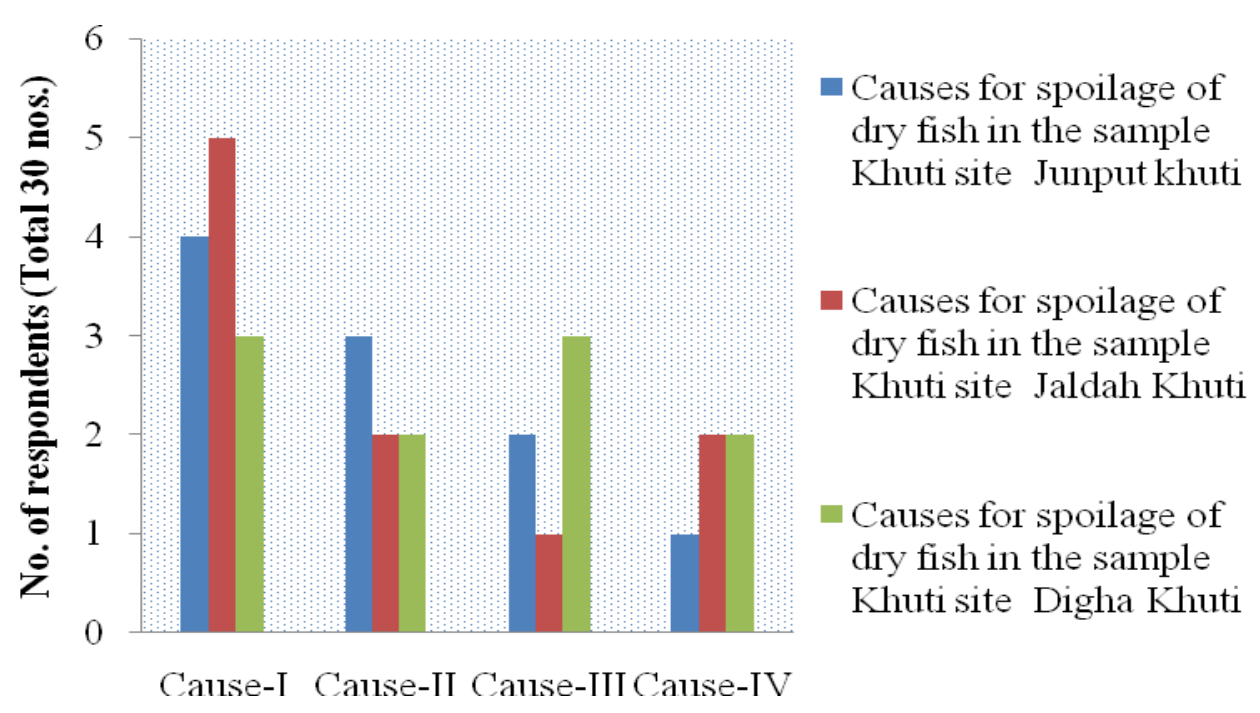

Table.1 Different marketing channels in Dry fish marketing

\begin{tabular}{c|l}
\hline Channel I & Fisher-Fish processor-Paikers-Wholesaler-Retailer-Consumer (45\%) \\
\hline Channel II & Fisher-Fish processor- Wholesaler-Retailer-Consumer (25\%) \\
\hline Channel III & Fisher-Fish processor- Wholesaler- Consumer (10\%) \\
\hline Channel IV & Fisher-Fish processor- Wholesaler-Exporters-Consumer (20\%)
\end{tabular}

Table.2 Price spread of dry fishes in different marketing channels in the selected study area in Purba Medinipore district of West Bengal (Rs. /kg)

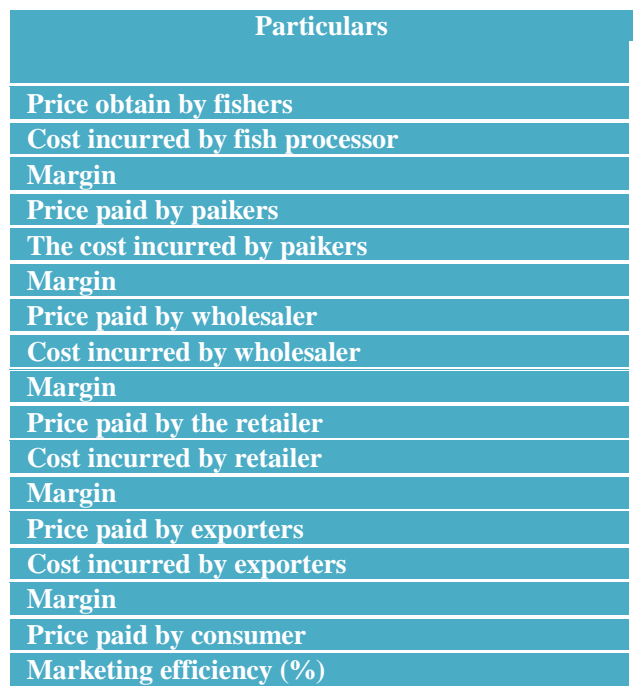

\begin{tabular}{|c|c|c|c|}
\hline \multicolumn{4}{|c|}{ Marketing channel } \\
\hline I & II & III & IV \\
\hline $14.00(7.78)$ & $18.00(10.28)$ & $24.00(15.48)$ & $19.00(11.04)$ \\
\hline $82.00^{*}(45.55)$ & $85.50 *(48.85)$ & $93.50 *(60.32)$ & $92.00^{*}(53.48)$ \\
\hline $11.50(6.39)$ & $13.05(7.45)$ & $12.45(8.03)$ & $15.50(9.01)$ \\
\hline $107.50(59.73)$ & - & - & - \\
\hline $15.30(8.50)$ & - & - & - \\
\hline $4.50(2.50)$ & - & - & - \\
\hline $127.30(70.73)$ & $117.0(66.75)$ & $129.45(83.51)$ & $126.50(73.25)$ \\
\hline $22.50(12.50)$ & $22.00(12.57)$ & $19.50(12.58)$ & $13.50(7.84)$ \\
\hline $7.50(4.17)$ & $8.50(4.85)$ & $5.55(3.08)$ & $6.45(3.75)$ \\
\hline $157.30(87.39)$ & $147.50(84.28)$ & - & - \\
\hline $18.50(10.28)$ & $20.25(11.57)$ & - & - \\
\hline $4.2(2.34)$ & $7.25(4.14)$ & - & - \\
\hline- & - & - & $146.45(85.14)$ \\
\hline- & - & - & $19.50(11.34)$ \\
\hline- & - & - & $6.05(3.51)$ \\
\hline $180.00(100.00)$ & $175.00(100.00)$ & $155.00(100.00)$ & $172.00(100.00)$ \\
\hline 7.78 & 10.28 & 15.48 & 11.04 \\
\hline
\end{tabular}

Note: Figures within the parentheses indicate percentages in consumer price.

* To produce $1 \mathrm{~kg}$ raw fish to $1 \mathrm{~kg}$ dry fish Rs. $23.76 / \mathrm{kg}$ is needed. As it was observed, average $75 \%$ weight loss occurs during drying, so $1 \mathrm{~kg}$ dry fish obtain from $4 \mathrm{~kg}$ raw fish. Thus Cost incurred by a fish processor inmarketing channel-I to produce $1 \mathrm{~kg}$ dry fish is Rs.95.04 (Rs.23.76×4) and so on. 
Table.3 Selected species-wise price spread of dry fishes in different marketing channels in the selected study area in Purba Medinipore district of West Bengal

\begin{tabular}{|c|c|c|c|c|c|c|c|c|c|c|c|c|c|}
\hline \multirow[t]{2}{*}{ Species } & \multicolumn{3}{|c|}{ Processor } & \multicolumn{3}{|c|}{ Paikers } & \multicolumn{3}{|c|}{ Wholesaler } & \multicolumn{3}{|c|}{ Retailer } & \multirow{2}{*}{$\begin{array}{c}\text { Consumer } \\
\text { Market } \\
\text { price }\end{array}$} \\
\hline & $\begin{array}{c}\text { Production } \\
\text { price }\end{array}$ & $\begin{array}{c}1^{\text {st }} \\
\text { stage } \\
\text { selling } \\
\text { price }\end{array}$ & $\begin{array}{c}\% \\
\text { profit }\end{array}$ & $\begin{array}{c}\text { Processing } \\
\text { price }\end{array}$ & $\begin{array}{c}\text { 2nd } \\
\text { stage } \\
\text { selling } \\
\text { price }\end{array}$ & $\begin{array}{c}\% \\
\text { profit }\end{array}$ & $\begin{array}{c}\text { Processing } \\
\text { price }\end{array}$ & $\begin{array}{c}\text { 3rd } \\
\text { stage } \\
\text { selling } \\
\text { price }\end{array}$ & $\begin{array}{c}\% \\
\text { profit }\end{array}$ & $\begin{array}{c}\text { Processing } \\
\text { price }\end{array}$ & $\begin{array}{c}4^{\text {th }} \\
\text { stage } \\
\text { selling } \\
\text { price }\end{array}$ & $\begin{array}{c}\% \\
\text { profit }\end{array}$ & \\
\hline Harpodon nehereus & 104 & 130 & 20.00 & 18 & 148 & 12.16 & 21 & 169 & 12.43 & 25 & 194 & 12.89 & 194 \\
\hline Trichiurus lepturus & 95 & 115 & 17.39 & 16 & 131 & 12.21 & 20 & 151 & 13.25 & 21 & 172 & 12.21 & 172 \\
\hline Setipinna phasa & 85 & 105 & 19.05 & 15 & 120 & 12.50 & 13 & 133 & 9.77 & 23 & 156 & 14.74 & 156 \\
\hline Escualosa thoracata & 75 & 90 & 16.67 & 12 & 102 & 11.76 & 19 & 121 & 15.70 & 18 & 139 & 12.95 & 139 \\
\hline Rastraliger kanagurta & 77 & 95 & 18.95 & 16 & 111 & 14.41 & 17 & 128 & 13.28 & 20 & 148 & 13.51 & 148 \\
\hline $\begin{array}{l}\text { Metapenaeus } \\
\text { monoceros }\end{array}$ & 74 & 90 & 17.78 & 10 & 100 & 10.00 & 15 & 115 & 13.04 & 19 & 134 & 14.18 & 134 \\
\hline
\end{tabular}

Table.4 Constrain face by the dry fish processor

\begin{tabular}{|c|c|c|c|c|}
\hline \multirow[t]{2}{*}{ Rank } & \multirow[t]{2}{*}{$\begin{array}{l}\text { Fish drying constrain (according to the } \\
\text { majority) }\end{array}$} & \multicolumn{3}{|c|}{$\begin{array}{l}\text { Constraints in the dry fish industry in the sample Khuti site } \\
\text { (More than one item stated) }\end{array}$} \\
\hline & & Junputkhuti & Jaldhakhuti & Dighakhuti \\
\hline I. & Capital constrain & 9 & 7 & 8 \\
\hline I. & The crisis of raw material & 6 & 6 & 7 \\
\hline I. & A higher number of middlemen & 6 & 5 & 6 \\
\hline I. & Poor infrastructural facilities & 5 & 6 & 4 \\
\hline Y. & Low market price & 4 & 3 & 3 \\
\hline I. & Poor storage facilities & 2 & 3 & 2 \\
\hline
\end{tabular}


It was observed that the farmers did not sell fish directly to the consumers. The major existing marketing channels were identified and are presented in Table 1.

A perusal of Table 1 reveals that channel I (Fisher-Fish processor-Paikers-WholesalerRetailer-Consumer) is the most popular marketing mode for dry fishes, and it is transacting about 45 percent of the total volume of transactions, and channel II (Fisher-Fish processor- Wholesaler-RetailerConsumer) is the second popular marketing system which accounts for about 25 percent of the total volume of transactions.

\section{Price spread analysis}

The price spread of dry fish was calculated across different identified marketing channels. Fish passes through several intermediaries before it reached the consumer and each step involved some cost and margins to the intermediaries. The results of price spread analysis for dry fish markets of PurbaMedinipore district of West Bengal are presented in Table 2.

A perusal of Table 2 reveals that the fisher's share in consumer's rupee was highest in channel III (Fisher-Fish processorWholesaler- Consumer) at 15.48 per cent. The fisher's share in consumer's rupee decreased with increase in the length of marketing channel due to the involvement of more number of intermediaries. Thus the fisher's share in consumer's rupee was lowest in Channel-I (Fisher-Fish processor-PaikersWholesaler-Retailer-Consumer) at 7.78 percent. The highest price spread was observed in the longest marketing channel due to the involvement of the highest number of marketing intermediaries.

Marketing efficiency was highest in the shortest marketing channel, i.e. channel III
(Fisher-Fish processor- WholesalerConsumer) and lowest in the longest channel I (Fisher-Fish processor-Paikers-WholesalerRetailer-Consumer). The variations in fisher's share in consumer's rupee resulted due to the presence of intermediaries and their marketing functions. This type of findings agrees with Kashyap et al., 2013. In case of margin, it was observed that paikers made the lowest one whereas fish processor made the highest.

A perusal of Table 3 reveals that the Harpodon nehereus is the most preferred dry fish in all three khuties because of abundantly available, take lesser time to completely dry. It was also observed that it had the highest market price (Rs.194/kg), followed by Trichiurus savala (Rs.172/kg), Setipinna phasa (Rs.156/kg), Rastraliger kanagurta (Rs.148/kg), Escualosa thoracata (Rs.139/kg) and Metapenaeus monoceros (Rs.134/kg).

In case of production price also Harpodon nehereus was the highest one having Rs.104/kg followed by Trichiurus savala (Rs.95/kg), Setipinna phasa (Rs.85/kg), Rastraliger kanagurta (Rs.77/kg), Escualosa thoracata (Rs.75/kg) and Metapenaeus monoceros (Rs.74/kg) (Fig. 2 and Fig. 5).

The study also reveals that profit percentage (Figure 3) was highest for dry fish processor compare to paikers, wholesaler and retailer, but in case of processing price (Figure 4) it was highest for the retailer.

\section{The labour cost of fish drying activities}

Labour charge plays a vital role in the dry fish industry, and it has an intimate relationship in profit-making and its total economics. During the survey, it was noticed that male labours got their wages on a monthly basis whereas females worked only daily basis. Their wages varied from drying points to drying points, 
but it doesn't vary at large scale. Male workers work 7.00 a.m. to 8.00 p.m. depending upon the working load while female workers work 7.00 a.m. to 4.00 p.m. Females worker are mainly involved in dressing and sorting activities whereas male workers handle the whole drying process other than dressing and sorting of fish. Rabbanee et al., (2012) studied about women involvement in dry fish value chain approaches towards sustainable livelihood where they found women workers were involved in different income generating activities like drying, sorting and grading, cleaning and salting etc. that supports the finding of the present study.

The average daily wages of male and female labour was recorded Rs. 300 and Rs. 170, respectively including meal charge (Fig. 6). The average monthly wages of male labour is Rs.9000. There was a distinct difference in the daily wages of male and female labour. Male labour got daily Rs.23 per hour, but the female labour got only Rs.18. per hour which indicated the prevalence of gender discrimination in fish drying labours. This finding agrees with Marine et al., (2015).

\section{Chemicals used in fish drying}

In Jaldhakhuti and Dighakhuti, fish processors didn't use any type of chemicals or preservatives to store the dry fishes for a long time both during processing and storage because their products were sold within a very short period of time. But in Junputkhuties, few processors used insecticide for long time storage and prevention of blowflies' infestation in dried fish. Most citable of them is Chlorpyrifos $20 \mathrm{EC}$. As the processors have no knowledge about the action of insecticide, does limit and residual effects of chemicals, they use 10-15drops of pesticides in 80 litres of water during washing of fresh fish. The use of insecticide is reduced on sunny days. Reza et al., (2005) studied the traditional drying activities of commercially important marine fishes in the coastal region of Bangladesh and observed that the processors soak the raw fishes in various kinds of insecticides including DDT, Nogos (Dichloroves) prior to drying with concentration ranging from 20-80 ppm (parts per million).

\section{Export status of dry fish}

The study reveals that out of 30 khuti owners of the selected area, most of the respondents (15.6 nos. $152 \%)$ sell their good quality dry fish to the big traders who in turn export their end product outside the districts as well as to other states and the rest (14.4 nos./48\%) of the respondents sell their end products in the local markets of the respective districts. Generally, the quality end product suitable for human consumption is exported to several states of India and as well as in abroad. In India, the end product is exported to the states like Assam, Bihar, Uttar Pradesh, Odisha, Tripura, Manipur and other North-Eastern states. It is also exported to foreign countries namely Bangladesh, Myanmar, Nepal, China and Pakistan. As such 52\% of the fish-curers undertake export of dry fish mostly to Bangladesh through middlemen/traders and earn good amount of money. The same type of observation was noticed by Samanta et al., 2016. Saha (1970) stated that the people of the districts of Chittagong, Barishal, Khulna, Mymensing of Bangladesh, prefer dry fish.

\section{Causes for Spoilage of Dry fish}

During the study, it was revealed that many factors are responsible for the spoilage of dry fish which cause a huge economic loss every year, out of them mainly poor quality raw fish, environmental conditions, mishandling and pests, spoilage of fishes are reported many times by the fish-curers resulting in deteriorated quality end products. 
To identify causes for spoiling the perusal of the Figure 7 indicates out of total respondents (30 nos.) $40 \%$ khuti owners indicates that "Due to heavy rain during off-season" as first and foremost cause, second cause for spoiling has been identified 23\% as "Due to moisture content in air", third cause for spoiling has been identified by $20 \%$ as "Due to infestation of pests (insects, rats etc.)". The fourth cause has been perceived by $17 \%$ of respondents is "Due to cloudy weather drying does not take place properly".

\section{Constraints}

The dry fish processor encountered various constraints which are enlisted in Table 4. According to the order of priority, the majority the constraints (more than one reason) are enlisted. The respondents perceived "Capital constraint" as their main problem (24) as $77.41 \%$, followed by "Crisis of raw material" for fish drying has been perceived as their second constraint (19) as $63.33 \%$.

The dry fish processor has expressed third important constraint as "high degree of dependency on middlemen" (17) as $56.66 \%$. "Poor infrastructural facilities in the market" encountered as fourth constrain as (15) $50.00 \%$. After drying the fish, the dry fishers do not get a proper return from their sale due to "Low market price" which has been identified as the fifth constraint (15) as $33.33 \%$. The last constraint encountered by them was "Poor storage facilities" due to which storage dry fish quality deteriorate rapidly (7) as $23.33 \%$.

\section{Management strategy}

While there are many problems in this industry, there are no initiatives to solve the constraints. There are the following suggestions to overcome them.
Provision of loan facility with some special subsidy to overcome the problem of capital constrained.

The involvement of several marketing intermediaries which reduces producer's share in consumer's rupee and reduces marketing efficiency. Thus to facilitate an appropriate marketing opportunity which is free from the intervention of middleman, a Co-operative Society or as per Kishanmandi should form through which a proper marketing system with an appropriate method of monitoring in the market yard.

To facilitation of proper infrastructure and minimise the unhygienic handling of the dry fishes low-cost solar dryer device should be used.

A credit facility side-a-side insurance schemes may be incorporated to safeguard the fishers.

As women's participation having a lion's share of the process, different measures related to health, education of the children, sanitary condition, safe and quality accommodation is of utmost importance towards the growth of the industry.

Shifting from an underdeveloped sector towards a promising sector, first of all, it requires the attention of the government towards both the fishery and fishers related to the industry. In case of fishery, it requires a sustainable policy starting from the procurement of fishes, up-gradation of the process maintaining the hygiene and the quality of the product through branding along with an appropriate marketing opportunity free from intervention of the middleman. Credit facility side-a-side insurance schemes may be incorporated to safeguard the fishers. As women's participation had the lion's share of the process, different measures related to 
health, education of the children, sanitary condition, safe and quality accommodation is of utmost importance towards the growth of the industry. With a synergistic effect of the above clauses obviously, make a turn of the industry towards the prosperity of both the industry and its allied community in near future meeting up the protein security of the underprivileged humanity of the country.

\section{References}

Anon. (1993). Indian fisheries statistic at a glance. Department of agriculture \& cooperation, KrishiBhavan. New Delhi. Pp 1 - 6.

Azam, K. (2002). In: Fishermen Community of Kuakata, Bangladesh: Fisheries Activities and Quality of Dried Fish. SUFER Project (DFID-UGC), Khulna University, 2002, pp. 2.

Bhat, T.H., Rizwana, Balkhi, M.H. and Bhat, B.A. (2013). An investigation on the indigenous method of fish drying in Bandipora district of Kashmir valley.Journal of Chemical, Biological and Physical Sciences, 3(3):1927-1932.

Bishnoi, T.K. (2005). In: Marketing of Marine Fisheries, Sonali Publication, New Delhi, pp. 74-76.

Clucas, I.J. (1982). In: Fish handling, preservation and processing in the tropics: Part 2, Tropical Products Institute, pp. 143.

Dan, S. S. (1985). Marine fishery of West Bengal coast. In: Marine Fisheries Information Service, Technical and Extension Series, 63: 6-8.

Das, A., Upadhyay, A.D., Kumar, N.R., Prakash, S., Debnath, B. and Datta, M. (2013). Marketing profile of selected fish markets of Tripura. Agricultural Economics Research Review, 26(1): 15120.

Felicia, S.C. and Patterson, J. (2003). Fungi in salted and dried fishes of Tuticorin,
Southeast coast of India.Fishery Technology, Cochin. India, 2: 412-417.

Flowra, F.A., Mohmud, M.S. and Mondal, R.C. (2012). Traditional fish drying activities and socio-economic status of dried fish processors of Chalan Beel area, Sirajganj, Bangladesh. Bangladesh Journal of Progressive Science \& Technology, 10: 65-68.

Gopakumar, K. (1994). Salted dried fish in India: a review 035 Int. J. Fishery Sci. Aquac.of methods and quality control.p 84.In: Champ BR, Highley (eds.). 1995. Fish drying in Indonesia. Proceedings of an international workshop held at Jakarta. Indonesia. 9-10 February 1994. ACIAR Proceedings No. 59: p 106.

GoWB (2016).Hand Book of Fisheries Statistics 2015-16, Department of Fisheries, Govt. of West Bengal.

Graikoski J.T. (1973). Microbiology of cured and fermented fish. In: Microbial safety of fishery products, edited by Chichester and Grahm, H.D., pp. 97110.

Immaculate, K., Sinduja, P., Velammal, A. and Jamila, P. (2013). Quality and shelf life status of salted and sun dried fishes of Tuticorin fishing villages in different seasons. International Food Research Journal, 20(4): 1855-1863.

Marine, S.S., Sayeed, M.A., Barman, P.P., Begum, R., Hossain, M.M. and Alam, M.T. (2015). Traditional methods of fish drying: An explorative study in Sylhet, Bangladesh. International Journal of Fishery Science and Aquaculture, 2(1): 28-35.

MPEDA. (2013). 19th India International Seafood Show at Chennai Trade Centre, Chennai. In: Press Release (24 JUNE 2013), Maine Product Export Development Agency.

Payra P., Maity R., Maity S. and Mandal B. (2016). Production and marketing of dry fish through the traditional practices in 
West Bengal coast: Problems and prospect. International Journal of Fisheries and Aquatic Studies, 4(6): $118-123$.

Rabbanee, F.K., Yasmin, S. and Haque, A., (2012). Women involvement in dry fish value chain approaches towards sustainable livelihood. Australian Journal of Business and Management Research, 1(12): 42-58.

Reza, M.S., Bapary, M.A.J., Azimuddin, K.M., Nurullah, M. and Kamal, M. (2005).Studies on the traditional drying activities of commercially important marine fishes of Bangladesh.

Saha, K.C. (1970). Sun-Dried Fish Trade and Other Fish By-Products. In: Fisheries of West Bengal, pp. 87-89.

Samad, M.A., Galib, S.M. and Flowra, F.A. (2009).Fish drying in ChalanBeel areas. Bangladesh Journal of Scientific and Industrial Research, 44(4): 461466.

Samanta, C., Bhaumik, U. and Patra, B.C. (2016). International Journal of Current Research and Academic Review. International Journal of Current Research and Academic Review, 4(5): 84-100.
Shakila, R. J., Vijayalakshmi, K. and Jeyasekaran, G. (2003). Changes in histamine and volatile amines in six commercially important species of fish of the Thoothukkudi coast of Tamil Nadu, India stored at ambient temperature. Food Chemistry, 82(3): 347-352.

Shyam, S.S., Rahman, M.R. and Nashad, M. (2016).Economic analysis of fish drying units in Kozhikode, Kerala. Discovery Nature, 10(25): 1-8.

Sivaraman G.K., Visnuvinayagam S. and Jha A.K. (2015).Microbiological spoilage of dried fishes. Indian Council of Agricultureal Research. New Delhi.

Soegiyono. Problems Associated with Dried Fish Agribusiness in Indonesia, In: Champ BR, Highley (eds.). Fish drying in Indonesia. Proceedings of an international workshop held at Jakarta. Indonesia. 9-10 February 1994. ACIAR Proceedings, 1995, No. 59: pp. 21.

Suparno. Fish Salting and Drying Studies in Indonesia, In: Champ BR, Highley (eds.). 1995. Fish drying in Indonesia. Proceedings of an international workshop held at Jakarta. Indonesia. 910 February 1994. ACIAR Proceedings, 1994, No. 59: pp. 61-62.

\section{How to cite this article:}

Soumyadip Purkait, Somen Sahu, Bostanul Arefin, Subir Kumar Pradhan, Anisha Sharma, Satyanarayan Boda, Sutanu Karmakar and Saymantaka Sahu. 2018. Marketing Profile of Dry Fish in Digha Coast of West Bengal. Int.J.Curr.Microbiol.App.Sci. 7(10): 3457-3470. doi: https://doi.org/10.20546/ijcmas.2018.710.401 